\title{
MENINGKATKAN KEMAMPUAN KOMUNIKASI MATEMATIS MELALUI PEMBELAJARAN BERBASIS MASALAH
}

\author{
Mikrayanti $^{* 1}$, Nur Baeti ${ }^{1}$, Ika Wirahmat ${ }^{1}$ \\ ${ }^{1}$ Program Studi Pendidikan Matematika, STKIP Bima \\ "Email korespondensi: kenisha.mikrayanti@gmail.com
}

\begin{abstract}
ABSTRAK
Penelitian ini bertujuan untuk mengetahui perbedaan peningkatan kemampuan komunikasi matematis siswa yang mengikuti pembelajaran berbasis masalah dengan siswa yang mengikuti pembelajaran konvensional pada sekolah kategori baik, cukup dan kurang. Desain penelitian menggunakan Kuasi eksperimen Nonequivalent Control Group Design dengan teknik Purposive Sampling. Populasi dalam penelitian ini adalah seluruh siswa SMA kelas XI di Kabupaten Bima. Sampel penelitiannya adalah siswa SMA kelas XI masingmasing mewakili sekolah kategori baik, cukup dan kurang. Instrumen penelitian ini adalah tes kemampuan komunikasi matematis dan lembar observasi. Analisis data dilakukan secara kuantitatif dan kualitatif. Analisis kuantitatif dilakukan dengan menggunakan uji $t$, uji $t^{\prime}$, uji $\mathrm{U}$ Mann-Whitney. Analisis kualitatif dilakukan untuk menelaah aktivitas siswa dan guru selama pembelajaran. Hasil penelitian menunjukkan bahwa terdapat perbedaan peningkatan kemampuan komunikasi matematis antara siswa yang mendapat pembelajaran berbasis masalah dengan siswa yang mendapat pembelajaran konvensional pada sekolah kategori baik, cukup dan kurang. Peningkatan kemampuan komunikasi matematis siswa yang belajar dengan menggunakan pembelajaran berbasis masalah pada sekolah kategori cukup lebih tinggi daripada siswa pada sekolah kategori baik dan kurang. Pada pembelajaran konvensional peningkatan kemampuan komunikasi matematis siswa sekolah kategori baik dan cukup lebih tinggi daripada sekolah kategori kurang.
\end{abstract}

Kata Kunci: pembelajaran berbasis masalah, kemampuan komunikasi matematis.

\begin{abstract}
This research aims to determine the differences in the increase in mathematical communication ability of students who take part in problem-based learning with students who follow conventional learning at school in the categories of good, enough and less. The design of this research used quasi-experimental Nonequivalent Control with purposive sampling technique. The population of this research was student of senior high school grade XI in Bima district. The sample was student of senior high school graders XI, each of wich represents a school in category of good, enough and less. The instruments used in this research were a form of communication ability test and observation sheet. data analysis is done quantitatively and qualitatively. Quantitative analysis using t-test, $t$ '- test and $U$ mann-Whitney test. Qualitatif analysis is conducted to examine the activities of students and teacher during learning. The results of this research indicated that there was a differences of students' in the increase in mathematical communication ability who followed problem-based learning with students
\end{abstract}


who received conventional learning at school in categories of good, enough and less. An increase in mathematical communication ability for students' who received problem based learning in schools enough category, higher than students in schools good and less category. In conventional learning, the increase of mathematical communication ability in the schools good and enough category, higher than students in schools less category.

Keywords : Problem based learning, Mathematical communication ability.

\section{PENDAHULUAN}

Kemajuan IPTEK dewasa ini, tidak terlepas dari peran matematika sebagai ilmu dasar. Disamping itu, matematika juga yang memiliki nilai-nilai strategis dalam menumbuhkembangkan cara berpikir logis, kritis, dan bertindak rasional, penataan nalar,pembentukan sikap mental, dan penerapan matematika diberbagai permasalahan baik yang terkait dengan kehidupan siswa sehari-hari maupun yang terkait dengan pengetahuan lain. Hal ini sesuai dengan tujuan umum pembelajaran matematika yang dirumuskan dalam NCTM (2000) dalam belajar matematika siswa dituntut untuk memiliki kemampuan: (1) Komunikasi matematis, (2) Penalaran matematis, (3) Pemecahan masalah matematis, (4) Koneksi matematis, dan (5) Representasi matematis. Dapat disimpulkan bahwa kemampuan matematis yang perlu diperhatikan dalam proses pembelajaran salah satunya adalah kemampuan komunikasi matematis.

Collins dkk (1995) (dalam Hulukati, 2005) menyebutkan bahwa salah satu tujuan yang ingin dicapai dalam pembelajaran matematika adalah memberikan kesempatan seluas-luasnya kepada para siswa untuk mengembangkan dan mengintegrasikan keterampilan berkomunikasi melalui lisan maupun tulisan, modelling, speaking, writing, talking, drawing, serta mempresentasikan apa yang telah dipelajari. Untuk mendukung pembelajaran yang efektif, guru harus membangun komunitas kelas yang kondusif sehingga para siswa bebas untuk mengekspresikan pemikirannya seperti mengungkapkan ide, menciptakan model serta mengatur dan menggabungkan pemikiran matematika mereka lewat komunikasi. Dengan komunikasi baik lisan maupun tulisan dapat membawa siswa pada pemahaman yang mendalam tentang matematika dan dapat memecahkan masalah dengan baik. Seperti apa yang dikemukakan Cockroft (Shadiq, 2004), 'We believe that all these perceptions of the usefulness of mathematics arise from the fact that mathematics provides a means of communication which is powerful, concise, and unambiguous'. Pernyataan ini menunjukkan tentang perlunya para siswa belajar matematika dengan alasan bahwa matematika merupakan alat komunikasi 
yang sangat kuat dan berpengaruh (powerful), teliti dan tepat (concise), dan tidak membingungkan (unambiguous).

Komunikasi matematis perlu menjadi perhatian dalam pembelajaran matematika, sebab melalui komunikasi siswa dapat mengorganisasi dan mengkonsolidasi berpikir matematisnya (NCTM 2000a) dan siswa dapat mengeksplor ide-ide matematis (NCTM, 2000b). Permasalahan kemampuan komunikasi siswa ini didasarkan pada penelitian Rohaeti (2003), Wihatma (2004) bahwa rata-rata kemampuan komunikasi siswa berada pada kualifikasi kurang dan dalam mengkomunikasikan ide-ide matematis kurang sekali. Sejalan dengan penelitian yang dilakukan oleh Atun (2006) yang menyimpulkan kemampuan komunikasi matematis siswa SMA masih rendah. Ungkapan senada juga sejalan dengan penelitian yang dilakukan oleh Subagiyana (2009) mengenai komunikasi matematis siswa, hasil yang diperoleh dari penelitiannya adalah rata-rata kelompok eksperimen 9,25 (39,38\%) hal ini masih tergolong rendah dari skor ideal 24 dan rata-rata kelompok kontrol 8,25 (28,95\%), jadi perbedaan peningkatannya cuma 10,43 .

Dari permasalahn tersebut, guru sebagai salah satu faktor penting penentu keberhasilan pembelajaran berperan dalam merencanakan, mengelola, mengarahkan dan mengembangkan materi pembelajaran termasuk di dalamnya pemilihan model, pendekatan atau metode yang digunakan sangat menentukan jenis interaksi pembelajaran yang dilakoni siswa sekaligus keberhasilan pengajaran matematika. Hal ini senada dengan pendapat Wahyudin (2003) bahwa salah satu cara untuk mencapai hasil belajar yang optimal dalam mata pelajaran matematika adalah jika para guru menguasai materi yang akan diajarkan dengan baik dan mampu memilih strategi atau metode pembelajaran dengan tepat dalam setiap proses pembelajaran. Agar guru tidak terjebak dalam pembelajaran yang hanya sekedar mentransfer pengetahuan, maka salah satu model pembelajaran yang dapat diterapkan dalam pembelajaran matematika adalah pembelajaran berbasis masalah.

Dalam pembelajaran berbasis masalah guru tidak menyajikan konsep matematika dalam bentuk yang sudah jadi, namun dengan menghadapkan siswa pada suatu masalah yang didalamnya ada fakta, situasi, keadaan yang dapat berpotensi menimbulkan konflik kognitif pada siswa. Dengan segenap pengetahuan dan kemampuan yang telah dimilikinya, siswa dituntut untuk menyelesaikan masalah yang kaya dengan konsep-konsep matematika (rich in contexts) dan memungkinkan siswa memecahkannya dengan strategi yang berbeda-beda. 
Adapun karakteristik dari pembelajaran berbasis masalah (Ismaimuza, 2010) adalah: 1) Memposisikan siswa sebagai pemecah masalah yang handal; 2) Mendorong siswa untuk mampu menemukan masalah dan mengelaborasinya dengan mengajukan dugaan-dugaan, mengidentifikasi, membuat hubungan dan merencanakan penyelesaian; 3) Memfasilitasi siswa untuk mengeksplorasi berbagai alternatif jawaban dan implikasinya; 4) Melatih siwa untuk terampil menyajikan temuan, dan 5) Membiasakan siswa untuk melakukan evaluasi dan refleksi tentang cara berpikir mereka dalam menyelesaikan masalah. Berdasarkan uraian yang dikemukakan di atas, maka penelitian ini difokuskan pada "Meningkatkan Kemampuan Komunikasi Matematis Siswa Sekolah Menengah Atas Melalui Pembelajaran Berbasis Masalah".

Berdasarkan uraian tersebut, maka masalah yang dikaji dalam penelitian ini adalah: Apakah terdapat perbedaan peningkatan kemampuan komunikasi matematis siswa yang mengikuti pembelajaran berbasis masalah dengan siswa yang mengikuti pembelajaran konvensional pada sekolah kategori baik, cukup dan kurang?.

\section{METODE PENELITIAN}

Penelitian ini merupakan penelitian kuasi eksperimen karena pemilihan sampel tidak secara random, tetapi menerima keadaan sampel apa adanya. Desain penelitian yang digunakan adalah Non-equivalent Control Group Design (Sugiyono, 2010). Populasi dalam penelitian ini adalah seluruh siswa SMA kelas 2 (Dua) di Kabupaten Bima Tahun Pelajaran 2011/2012. Pengambilan sampel dalam penelitian ini dilakukan dengan menggunakan teknik purposive sampling. Teknik purposive sampling adalah teknik penentuan sampel dengan pertimbangan tertentu (Sugiyono, 2010).

Sampel yang digunakan dalam penelitian ini adalah 6 (enam) kelas siswa SMA kelas XI masing-masing mewakili sekolah kategori baik, cukup dan kurang yang ada di Kabupaten Bima. Untuk memperoleh data dalam penelitian ini digunakan dua macam instrumen penelitian yang terdiri dari dua jenis yaitu tes dan non-tes. Instrumen jenis tes merupakan tes kemampuan komunikasi matematis berupa tes berbentuk uraian sebanyak 5 soal. Sedangkan instrumen non-tes terdiri dari skala sikap siswa, dan lembar observasi. Analisis data dilakukan secara kuantitatif dan kualitatif. Analisis kuantitatif dilakukan dengan menggunakan uji t, uji t', uji U Mann-Whitney. Analisis kualitatif dilakukan untuk menelaah aktivitas siswa dan guru selama pembelajaran. 


\section{HASIL DAN PEMBAHASAN}

Berdasarkan pada data yang telah dianalisis, menunjukkan bahwa pembelajaran berbasis masalah pada tiga kategori sekolah dapat meningkatkan kemampuan komunikasi matematis siswa. Pada kemampuan komunikasi matematis peningkatannya terjadi pada kelas eksperimen, pada kelas kontrol peningkatannya hanya terjadi pada sekolah kategori baik saja, yaitu dari komunikasi tingkat rendah menjadi tingkat sedang, pada sekolah kategori cukup dan kurang tidak terjadi peningkatan. Secara umum rata-rata kemampuan komunikasi matematis siswa pada kelas eksperimen lebih tinggi daripada rata-rata siswa kelas kontrol. Berikut gambaran umum rata-rata peningkatan kemampuan komunikasi matematis pada tiga kategori sekolah.

Tabel 1. Rata-rata Gain Komunikasi Matematis

\begin{tabular}{cccc}
\hline \multicolumn{2}{c}{$\begin{array}{c}\text { Kemampuan yang } \\
\text { diukur }\end{array}$} & \multicolumn{2}{c}{$\begin{array}{c}\text { Kemampuan } \\
\text { Komunikasi } \\
\text { Matematis }\end{array}$} \\
\hline \multicolumn{2}{c}{ Pendekatan Pembelajaran } & PBM & PK \\
Kategori & Baik & 0,54 & 0,43 \\
Sekolah & Cukup & 0,63 & 0,43 \\
& Kurang & 0,42 & 0,31 \\
\hline
\end{tabular}

Berdasarkan pada Tabel di atas, terlihat bahwa terjadi peningkatan kemampuan komunikasi matematis siswa yang belajar dengan menggunakan pembelajaran berbasis masalah pada sekolah kategori cukup lebih tinggi daripada siswa pada sekolah kategori baik dan kurang. Hal inipun terjadi pada pembelajaran konvensional dimana kemampuan komunikasi pada sekolah kategori baik dan cukup lebih tinggi daripada sekolah kategori kurang. Kualifikasi gain pada sekolah kategori baik dan cukup, baik kelas eksperimen maupun kontrol termasuk tingkat sedang, sedangkan pada sekolah kategori kurang termasuk tingkat sedang dan rendah.

Keberhasilan pembelajaran berbasis masalah dalam meningkatkan kemampuan komunikasi matematis siswa terjadi karena dalam pembelajaran berbasis masalah siswa diberi keleluasaan untuk berinteraksi dengan temannya ataupun guru, saling berbagi, mengajukan pendapat atau ide sehingga konsep-konsep yang diperoleh digali secara mendalam dan bermakna. Melalui interaksi antara siswa, diharapkan terjadi pertukaran pengalaman belajar berbeda sehingga aksi mental dapat terus berlanjut sesuai dengan yang diharapkan. Sementara 
itu teknik scaffolding dapat digunakan selain untuk mengarahkan proses berpikir, juga untuk memberikan tantangan lanjutan sehingga aksi mental yang diharapkan dapat terjadi dengan baik.

Berdasarkan analisis data penelitian, terdapat temuan-temuan yang terjadi pada saat penelitian, di mana peningkatan kemampuan komunikasi matematis lebih tinggi untuk sekolah kategori cukup dibanding sekolah kategori baik dan kurang. Peningkatan kemampuan komunikasi matematis yang dicapai oleh siswa pada sekolah kategori cukup disebabkan oleh kerjasama yang berlangsung dengan baik dalam kelompok. Setiap anggota merasa bagian dari kelompok tersebut, akibatnya mereka mempunyai tanggung jawab yang sama untuk mencapai tujuan kelompok yaitu menyelesaikan masalah dengan baik.

Mereka saling berbagi pendapat, mendengarkan dan menanggapi pendapat teman dengan baik. Hal ini sesuai dengan pendapat Schaps, Lewis\&Watson (2003) menyatakan bahwa belajar kelompok menumbuhkan rasa sebagai bagian dari kelompok (sense of classroom community) dan memberi kontribusi positif kepada hasil belajar siswa. Hal ini disebabkan oleh motivasi belajar yang meningkat dan berkurangnya kecemasan siswa.

Selain itu pada sekolah kategori cukup, perbedaan kemampuan antara siswa yang pandai dan sedang tidak terlalu jauh. Keheterogenan kemampuan siswa ini dapat memicu motivasi siswa untuk belajar, dapat saling mendukung/membantu sehingga mempunyai kesempatan untuk saling bertanya kepada teman satu kelompok atau dengan bantuan/bimbingan guru sehingga dapat mengembangkan kemampuan potensialnya (Vygotsky, 1978). Hal ini sejalan pula dengan hasil penelitian Hooper dan Walker (Hulu, 2009) yang mencatat, bahwa adanya pengajaran teman sebaya, selain meningkatkan penghargaan dan kepercayaan diri, juga meningkatkan keterampilan komunikasi siswa. Hal ini membuat diskusi diantara siswa berlangsung cukup baik. Pada sekolah kategori baik peneliti tidak mengalami kesulitan dalam menerapkan pembelajaran berbasis masalah dalam peningkatan kemampuan komunikasi matematis siswa. Hal tersebut disebabkan kemampuan awal siswa yang cukup baik serta antusias siswa dalam belajar yang tinggi. Tetapi kendala yang terjadi pada sekolah kategori baik yaitu kuatnya kompetisi akademik antar siswa menyebabkan kecenderungan siswa untuk bersaing diantara teman kelompoknya. Setiap siswa ingin menunjukkan kemampuannya kepada siswa lain sehingga esensi yang terdapat dalam 
belajar kelompok seperti tanggung jawab, interaksi antar siswa dan komunikasi tidak terlaksana secara maksimal.

Berbeda dengan siswa pada sekolah kategori baik dan cukup, siswa pada sekolah kategori kurang sering mengalami "kebuntuan" dalam kelompok. Artinya terjadi situasi siswa tidak menemukan ide sehingga mereka tidak tahu apa yang harus dilakukan, informasi apa yang diperlukan dan bagaimana memperoleh informasi. Menurut Bell (1978) permasalahan yang muncul dalam pembelajaran matematika biasanya terjadi pada siswa yang kemampuannya kurang (low achievers) atau siswa yang lambat (slow learner).

Siswa yang termasuk ke dalam slow learner cenderung tidak dapat belajar matematika secepat dan sebaik yang diharapkan guru. Di samping itu, kebiasaan siswa pada sekolah kategori kurang yang masih terbawa dengan menggunakan pembelajaran konvensional, di mana siswa menerima pengetahuan secara langsung dari guru. Kondisi inilah yang membuat siswa menjadi kurang mandiri dalam belajar. Salah satu dampak dari ketergantungan yang tinggi terhadap guru, membuat siswa kurang mampu mengembangkan kemampuan berfikirnya.

\section{KESIMPULAN}

Berdasarkan hasil pengolahan data, analisis, temuan dan pembahasan diperoleh kesimpulan: Terdapat perbedaan peningkatan kemampuan komunikasi matematis antara siswa yang mendapat pembelajaran berbasis masalah dengan siswa yang mendapat pembelajaran konvensional pada sekolah kategori baik, cukup dan kurang. Peningkatan kemampuan komunikasi matematis siswa yang belajar dengan menggunakan pembelajaran berbasis masalah pada sekolah kategori cukup lebih tinggi daripada siswa pada sekolah kategori baik dan kurang. Pada pembelajaran konvensional peningkatan kemampuan komunikasi matematis siswa sekolah kategori baik dan cukup lebih tinggi daripada sekolah kategori kurang.

\section{REKOMENDASI}

Rekomendasi dalam penelitian ini yaitu kemampuan komunikasi matematis siswa perlu ditingkatkan melalui pendekatan pembelajaran berbasis masalah yang terakomodir pada fase kegiatan mengembangkan dan menyajikan hasil karya, karena melalui kegiatan tersebut mampu mengembangkan argumen siswa. Selain itu, perlu dilakukan penelitian lebih lanjut tentang bagaimana pelaksanaan dan upaya-upaya yang dapat dilakukan untuk meningkatkan 
kemampuan komunikasi matematis dengan pembelajaran berbasis masalah pada siswa sekolah kategori kurang.

\section{UCAPAN TERIMAKASIH}

Penulis menyampaikan ucapan terima kasih yang sebesar-besarnya kepada: Kepala SMA Negeri 1 Bolo, Kepala MAN 3 Bima, dan Kepala SMA PGRI Bolo yang telah mengizinkan penulis untuk mengadakan penelitian dan semua pihak yang telah membantu dalam penyelesaian penelitian ini baik secara langsung maupun tidak langsung.

\section{REFERENSI}

Atun, I. (2006). Pembelajaran Matematika dengan Strategi Kooperatif Tipe STAD Untuk Meningkatkan Kemampuan Pemecahan Masalah dan Komunikasi Siswa SMA. Tesis pada PPS UPI Bandung: Tidak diterbitkan.

Bell, F. H. (1978). Teaching and Learning Mathematics in Secondary Schools. Dubuque: Wm.C. Brown Company Publishers.

Hulu, P. (2009). Meningkatkan Kemampuan Penalaran Matematik Siswa SMP Menggunakan Pendekatan Pembelajaran Berbasis Masalah. Tesis pada PPs UPI. Bandung: Tidak diterbitkan.

Hulukati, E. (2005). Mengembangkan Kemampuan Komunikasi dan Pemecahan Masalah Matematis Siswa SMP Melalui Pembelajaran Generatif. Disertasi pada PPs UPI. Bandung: Tidak diterbitkan.

Ismaimuza, D. (2010). Kemampuan Berpikir Kritis dan Kreatif Matematis Siswa SMP Melalui Pembelajaran Berbasis Masalah Dengan Strategi Konflik Kognitif. Disertasi pada PPs UPI. Bandung: Tidak Diterbitkan.

NCTM. (2000). Principles And Standards For School Mathematics. Reston, VA: NCTM.

NCTM. [National Council of Teachers of Mathematics]. (2000a). Principles And Standards For School Mathematics. Reston, VA: NCTM.

NCTM. [National Council of Teachers of Mathematics]. (2000b). Mathematics Assesment: A Practical Handbook for Grades 6-8. Reston: VA: NCTM.

Rohaeti, E. (2003). Pembelajaran dengan Metode IMPROVE untuk Meningkatkan Pemahaman dan Kemampuan Komunikasi Matematik Siswa SLTP. Tesis Magister pada PPS UPI Bandung: tidak diterbitkan. 
Shadiq, F. (2004). Pemecahan Masalah, Penalaran dan Komunikasi. Yogyakarta: PPPG Matematika.

Subagiyana. (2009). Peningkatan Kemampuan Pemahaman dan Komunikasi Matematis Sisiwa SMP Menggunakan Model Pembelajaran Kooperatif Tipe Team-Assisted Individualization (TAI) dengan Pendekatan Kontekstual. Bandung: PPS UPI (Tesis tidak diterbitkan).

Sugiyono. (2010). Metode Penelitian Pendidikan: Pendekatan Kuantitatif, Kualitatif, dan $R \& D$. Bandung: Alfabeta.

Vygotsky, L. S. (1978). Mind in society. Cambridge, MA: Harvard University Press.

Wahyudin. (2003). Matematika dan Kurikulum Berbasis Kompetensi. Mimbar Pendidikan. No.2 Tahun XXII. Bandung : University Press UPI.

Wihatma, U. (2004). Meningkatkan Kemampuan Komunikasi Matematik Siswa SLTP melalui Cooperative Learning Tipe STAD. Tesis pada PPS UPI Bandung: tidak diterbitkan. 